\title{
THE ROLE OF TURKISH WOMEN IN THE POLITICS OF OTTOMAN EMPIRE
}

\author{
* Professor Dr. Summer Sultana, Chairperson, Department of Political Science, \\ University of Karachi, Karachi - Pakistan \\ ** Muhammad Amin Sharif, Research Scholar, Area Study Center for Europe, University \\ of Karachi, Karachi - Pakistan
}

\begin{abstract}
:
This article is very important because the Sultanate of women has ruled nearly 130 years in the 16th and 17th centuries, when the women of the majestic harem of the Ottoman Empire [are true rulers of Ottoman Empire] and they have extraordinary influence on issues of the State and on the Ottoman Sultans. Ottoman Empire is one of the most prominent Empires in the history of humankind .It rules 623 years, more than six centuries. Its period starts from 1299 to 1923. It rules three continents and two seas .At its peak in $16^{\text {th }}$ century Ottoman Empire spanned an area from Hungary to Yemen from north to south and from Algeria in the west to Iraq in the East. Ottoman Empire has strong rulers like Osman 1, Orhan, Murad 1 [martyr], Bayezid 1, Mehmed 11[Faith], Selim 1[The strong], Suleiman [The Magnified], all of them are great conquerors. They defeat European combined powers many times in all the battles.
\end{abstract}

\section{Introduction}

In 1243, the Mongols in the battle of Kosedag defeated the Seljuk's and their dominance ended. In the disorder that followed, another Turkish tribe got the chance to rise and gradually create the great Ottoman empire .Osman 1[Founder of Ottoman Empire] and declared himself as Sultan Osman 1 in 1299, thus laying the foundation of the long lasting Osmani or Ottoman Empire, which lasted till 1923. 
The phenomenal advance of the Ottoman continued till 1595 when the empire reach the zenith of its power under Suleiman the magnificent [son of Selim 1 and Hafsa Sultan]and spread over nine million sq.km in three continents.

The slow invisible decay of a century became manifest when the Ottomans failed in their second effort to storm Vienna in 1683, and in the next few years lost much of their territory in Europe including Portugal ,Hungary and Transylvania .In 1768-74 Ottoman lost the war against Russia.

It is very strange thing but 'The Sultanate of women' was a part of Ottoman Empire for 130 years from Hurrem Sultan to Turhan Sultan. These women are the mothers of Sultan's rule directly or indirectly .Ottoman Empire from the era of Suleiman the Magnificent [ His wife Hurrem Sultan is founder of Sultanate of women and ended in 1683 with the death of Turhan Sultan .During Sultanate of women many Sultans are minors and mentally disabled.

Majority of these women are concubines which become Sultan wives and then give birth to their children and when their husband death, when their sons become kings, they become Valide Sultan. Valide Sultan is most powerful rank after Sultan. These women improved the administration with the help of Great viziers like Resit Ali and Fuat Pasha, but the shattered finances could not led them succeed fully.

With the beginning of the $16^{\text {th }}$ century expansion of Ottoman Empire come to end after the defeat of battle of Vienna [capital of Austro Hungary Empire].

During the reign of Suleiman the Magnificent, it became clear that the Empire had reached its limits. In the reign of Suleiman (Babinger, 1977). "The merger of the harem in the Imperial Palace and as it became the first Sultan to be formally married", The woman [which is his concubine named [Roxlena] later known under the name of Hurrem Sultan. This step is very controversial, even at that time, [and not like by royal family itself and by Sultanate ministers]. However, this law, combined with the 


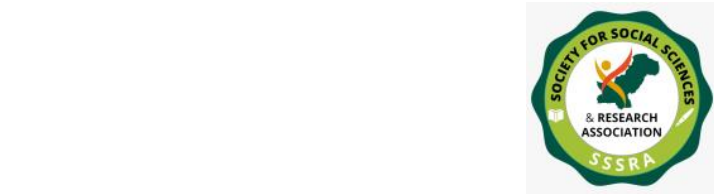

centralization of the Ottoman dynasty, has the women of the harem closer to real power that they had never been. Murat III even moved his personal residence of the palace, where exclusively - the servants and courtiers had previously surrounded him, to the Harem itself. As well, at the end of the years 1600, the wife and the mother of the Sultan have become two of the most important positions in the Ottoman government.

"By the middle of the 17th century, six Sultans had reigned, few of them were children when they arrived to the throne and others are mental." (Eversely, 1959). So in this situation, the Valida Sultan were become King practically and their decision are autonomous. However, ministers and Government officials did not easily accept this power. Even with a direct connection to the Sultan, the Valida Sultan often faced with the opposition of its ministers, army and as well as the danger of public attitude. It is not easy for women to handle this situation but women like Hurrem and Kosem manage it very well .They had gained the favor of the public by the construction of monuments and public works .Kosem Sultan is also very popular in military. She is known as best woman of 'Sultanate of women' Last majestic women is Turhan Sultan has contributed major part in the defense of the Empire, the expenditure of large sums of money on the reconstruction of the military equipment and especially on navy. When Turhan Sultan son Mehmed IV returns after a successful military campaign, she had a royal procession to his victory.

In spite of the fact that it is not religious convention yet the Valide [mother of Ottoman king] has held self-sufficient power and the Valide's of the Reign [mother of Ottoman king] of Women were talented government officials and were equipped for running a realm "As I already mentioned, the Sultanate of Women started with the marriage of Hurrem Sultan to Suleiman the Magnificent in 1531. Hurrem was Suleiman official wife. Hurrem was the first Sultana has to maintain diplomatic and personal relationships with foreign monarchs. In addition to maintaining diplomatic relations, she was also famous for her building and public work projects another large part of being Valide Sultan." (Inalcik, 1970). "After Hurrem, all women follow this tradition. Valida Sultan was conceivably the most important post in the Ottoman Empire after the Sultan " (Inalcik, 1970). 


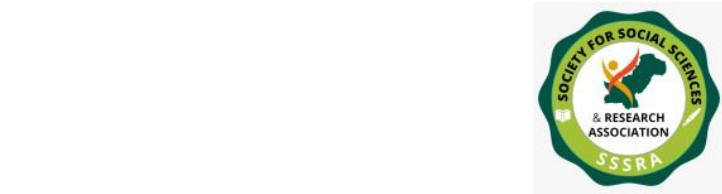

The mothers of Sultan have major powers and they influence on the affairs of the Ottoman Empire". In exacting, during 17th century, in period known under the name of "Sultanate of women", a series of ineffectual or minor Sultans increase the influential of Valida Sultan in matters of state. The most powerful and the best known of all the Sultans Valida in the history of the Ottoman Empire have been Hafsa Sultan, Mihrimah Sultan, Mahidevran, Nurbanu, Turhan , Kosem, Hurrem [Roxlena] and Safiye.

\section{Hurrem [Roxelana]}

Hurrem [Roxelana] entered the harem when she is around fifteen year old. Hurrem Sultan was born in 1502 in Poland. The year indicates that she is entered in the harem is unknown, but according to the researchers, she became the concubine of Suleiman around the time, Suleiman became the Sultan in 1520 after death of Selim 1.She is first official wife of any Ottoman king . Hurrem Sultan also gets the title of "Haseki Sultan" [chief wife of Sultan] .Suleiman write many poems for her also. Hurrem Sultan was born in 1502 and died in 1558.Very soon after her marriage she became the most famous of Suleiman consultant. She was origins from Polish city; formerly orthodox Christian .Few researcher's says that Hurrem wants revenge from Ottoman Empire of her nation slavery.

"Hurrem Sultan gives births her five children Princess Mihrimah Sultan, Prince Mehmed [born in 1521], Prince Abdullah, the Sultan Selim II [born in 1524 later become king] and Prince Bayezid"( Inalcik, 1970). The influence of Hurrem in the affairs of the State has not only made Hurrem Sultan one of the most powerful women, but also a most notorious figure in the history of Ottoman Empire, especially in the rivalry with Mahidevran [who was the chief consort of Suleiman before the Hurrem] and her son Mustafa, Prime Minister Pargali Ibrahim Pasha, and Kara Ahmed Pasha.

Hurrem and Princes Mahidevran were the rivals from the beginning. This rivalry increase so much [Mahidervan means one whose beauty never fades]. Hurrem Sultan jealous with the son of Mahidevran[Gulbahar 


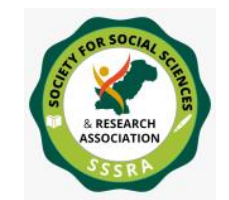

another wife of Suleiman] .Mahidervan was born in Albania in 1500.Mahidervan son's Mustafa was born in 1515.Mustafa[son of Mahidevran] was the most devoted and eldest among Suleiman sons .Mustafa was also most capable of all Suleiman son's. Traditionally, when a new Sultan came to power, all his brothers were killed in the aim of ensuring the stability of the Empire." (Babinger, 1977). This law is called Kardes Katliami "[which of course against the Islamic tradition].This law is started by Ottoman king Mehmat II. According to this law 'The son who inherits Sultanate has right to kills his brothers in the interest of world order.'

Prime Minister of Suleiman Ibrahim Pasha supported Mustafa [son of Mahidevran]. Hurrem generally took place at least in part responsible for the nomination of a descendant, although Hurrem [Roxelana] was the wife of Suleiman; Hurrem had no formal public role. This does not preclude, however, powerful Roxelana armed with political influence. In trying to avoid the putting to death and killing of Hurrem own sons, Roxelana has used her influence to eliminate those who have supported the succession of Mustafa as a future king of Ottoman Empire.

The commandant of the army of Suleiman, Ibrahim [big supporter of Mustafa] has many powers but in 1536, Suleiman executed him. It is believed that the influence of Hurrem has contributed to the decision of Suleiman. After three other major ministers in just eight years, Suleiman selected Hurrem son-in-law, Rustem Pacha, husband of Mihrimah, to become the Prime Minister. According to researchers, this is the big success of Hurrem Sultan.

Hurrem Sultan and the Prime Minister Rustem helped turn Suleiman against Mustafa and Mustafa was blamed for causing turmoil. Amid the crusade against Safavid Empire of Persia in Fifteen fifty three 1553, Suleiman ordered the execution and killing of Mustafa.

Suleiman dismissed Rustem and appointed Kara Ahmed as his Prime Minister in October 1553. However, almost two years later, Kara Ahmed was killed by Suleiman's order on sixth September 1555. It is said that the 
execution was due to political interfere of Hurrem Sultan, who wanted Rustem to become the Prime Minister again. After death of Kara Ahmed, Rustem Pasha became the Prime Minister again.

Negative role of Hurrem Sultan in executions of Prime Minister Ibrahim, Prince Mustafa, and Prime Minister Kara Ahmed are very popular, but one the other end, her contribution as right hand of Suleiman the Magnificent [known in Turkey as Kanuni or the lawgiver] in Empire progress never is ignore. No one can deny her administrative abilities; it was appreciated by Ottoman historians as well as by European diplomats, and researchers.

Hurrem role in international politics is very prominent. Hurrem died on 15 April 1558 at the age of 56 year.

\section{Nurbanu Sultan}

Nurbanu Sultan was the wife of the Ottoman Sultan Selim II [who has been placed thrown in 1556], as well as the mother of the Sultan Murad III (reign 1574-1595).Nurbanu was born in 1525. Nurbanu was one of the dominant personalities at the time was known as the Sultanate of women. Her real name was Cecelia Rachel. She has born in island of Paros, which was the part of Venice Empire. Nurbanu Sultan was belonging to Jewish family, when she enters in harem; she was only 12 year old. Hurrem Sultan gives her title of Afife Nurbanu Sultan, due to Nurbanu Sultan, intelligence and beauty Sultan Selim II would often ask her advice on in various subjects due to her good judgment [She as acted as an advisor to her husband Sultan Selim II. With the time, Nurbanu became the more favorite, because she was the wife of Ottoman Sultan Selim II, who has been placed on the throne in 1566, and the mother of Murad III.

During that her husband Selim was a prince Nurbanu Princes, had been the leader of the princely harem to Manisa. However, when Selim ascended to the throne, Nurbanu Sultan become her advisor and become his official wife and queen. (Babinger, 1977). "Nurbanu Sultan was shrewd diplomat and she establishes very friendly bilateral relation with France and allows France to open its Embassy in Istanbul capital of Turkey". 
She was a devoted wife and a loving mother and very faithful to Ottoman Empire .She give birth to one son and four daughters. The Ottoman Empire was far from being very stable as the clashes on the imperial throne were common. It is also not uncommon that the loser of having his entire family was murdered with him to prevent any possible problem. Nurbanu Sultan was however decided that when the time is ripe for her son to succeed to his father, there is nothing to interfere with this.

When the Sultan Selim II died in 1574, Prince Murad had been sent to serve as governor of Manisa. This would have been the perfect chance for someone to grab power with the Sultan death and his son far from the capital. Nurbanu realized this as much, if not more, than anyone realize and has taken prompt measures. When Nurbanu Sultan son Murad became the Sultan Murad III, she became Valida Nurbanu Sultan, the highest position; a woman could take in the Ottoman Empire. Unlike her forerunner Hurrem, Nurbanu Sultan, survived her husband and enjoyed complete power from 1574 to 1583 .

Nurbanu after became Valida the Sultan to her son Murad III and she successfully managed the government with the help of Prime Minister Sokollu Mehmet Pacha. Queen Catherine de Medici of France is her best friend. Both exchange gifts to each other.

Nurbanu has also friendly relations with Venice Empire, which not like by Empire of Geneva and one day Geneva spy give her poison which cause her death. She was died in 1683 at the age of 59 years.

During her nine years of regency (1574-1583), she ruled Ottoman Empire in extraordinary way .She considered one of the prominent women in Ottoman Empire

\section{Safiye Sultan}

Safiye Sultan was the wife of Murad III. Her real name was Sophia and she was the daughter of Governor of Corfu province of Venice Empire. Safiye Sultan was born in 1550. She took highest allowance as mother 


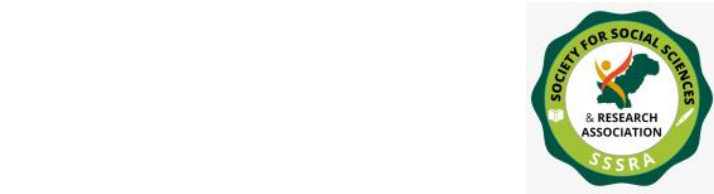

queen in the history of Ottoman Empire. At age of 13 year in 1563, she enters in harem as concubine. Safiye Sultan was also the mother of Mehmed III. Safiye [Sophia] is also one of the personalities at the time was known as the Sultanate of women." (Davison, 2015). She has lived in the Ottoman Empire as a noble during the reigns of seven Sultans: Suleiman the Magnificent, Selim II, Murad III, Mehmed III, Ahmed I, Mustafa I, and Osman II". On 26 May 1566, Safiye Sultan gave birth to son of Murad, the future king of Ottoman Empire Mehmed III, that year where Suleiman the Magnificent dies .Safiye had been the only concubine Murad before its accession, and it has continued to have a association with her for quite a long while in his Sultanate. In 1583, after the death of Nurbanu Sultan her mother in law she become the most powerful woman of Sultanate. Safiye Sultan has played as a Haseki, the rank conferred to less than a year after Murad is mounted on the throne. Safiye also enjoys as Mother of the Prince.

When Murad was died in year 1595, Safiye [Sophia] organized for her son Mehmed to succeed as Sultan and she became the Valida Sultan-one of the most powerful of the Ottoman History. Until the death of her son in year 1603, a party led by Safiye Sultan has determined the Ottoman policy. She was the chief consorts, her work prove that she belongs to peasant family. Safiye Sultan intervenes in all government matters in not only internal issues but also design new foreign policy. Queen Elizabeth I gives her gift of Gorgeous golden coach. Safiye Sultan was the richest woman in history off Ottoman Empire, during the war she help her son Sultan army even with her own pocket money.

As she also belong to Venice she has also friendly relation with Venice ambassador, she is so powerful that sometimes she appointed prime ministers and Sheikh-al-Islam, she also founded mosque al - Malika Safiyya in Cairo.

After the death of Mehmed III Safiye Sultan son her grandson Ahmed I became Sultan in 1603. One of Ahmed I first real choices was to confiscate his grandma of power. Safiye is additionally popular for the beginning of the development of the mosque Yeni, which was at long last finished in 


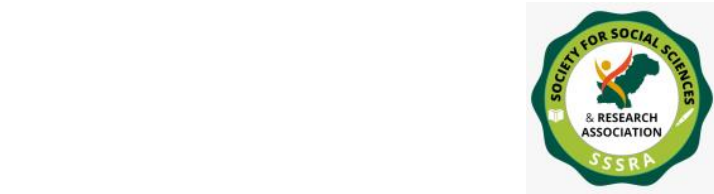

Pak. Journal of Int'L Affairs, Vol 2, Issue 2 (2019)

The Role Of Turkish Women ....

1665 by another Turhan Sultan. Safiye Sultan died in 1619 at the age of 69 years.

\section{Kosem Sultan}

Kosem Sultan also known as Sultan Mahpeyker [light of moon] has been a standout amongst the most dominant women in the Ottoman History. Kosem Sultan birth name is Anastasia. Kosem Sultan was born in 1589. Kosem Sultan was born in Tinos [island of Greece]. Kosem Sultan joined harem when she was only 15-year-old .Kosem reached the power and the political influence of the Ottoman Empire, when she became the wife of the Ottoman Sultan Ahmed I and Valida Sultan as the mother of Ibrahim and his brother Murad IV, and grandmother of Mehmed IV. Kosem Sultan is only Valida Sultan who see reign of six kings.

Kosem Sultan was one of the leading figures in the course of the Sultanate of women. Kosem has taken the importance at the beginning of the reign of Ahmed 1. Kosem Sultan is very loyal with her husband and with Ottoman Empire. She gives birth to five sons and three daughters. Due to her beauty and wisdom, Kosem Sultan attracts King Ahmed and he made her head of Harem. After death of Handan Sultan and execution of Safiye Sultan Ahmed, Kosem admitted to raise the top of the Imperial harem and she works has a deputy ruler of Sultanate for more than 30 years in period of her two sons and grandson. When Kosem Sultan husband died, she was only 28 years.

On 22 November 1617, after the death of Ahmed at a young age of 27, Ahmed brother Osman 2 become Sultan and Kosem Sultan retired in the former Palace during the reign of his brother-in-law Mustafa I and son-inlaw Osman II.

Kosem has come to power again when her son ascended to the Throne on September 10, 1623 as Murad IV. Because her son was a minor, she was appointed not only as a Valida Sultan, but also as a public servant Regent (NAIB-i-Sultanate) during the minority of her son [the ascent of her son on September 10, 1623 until May 18, 1632]. 


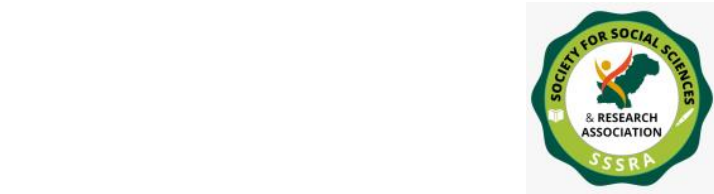

For ten years, Kosem Sultan rules the country very well and strengthens the Empire.In 1632, Murad IV want to become powerful and he dismiss Kosem Sultan as NAIB-i-Sultanate.

The other son of Kosem, Ibrahim, lived in prison of being the next of his brothers to be executed by order of Murad in 1635. His life has been save by the intercession of his mother Kosem Sultan after the death of Murad, Ibrahim [mentally unstable] has left the only prince survivor of the Ottoman Empire and in this way Kosem Sultan saves the Ottoman Empire. In 1640, Ibrahim succeeded his brother, but Ibrahim is mentally unstable to the rule. This has enabled the authority to continue Kosem. (Babinger, 1977). "He was encouraged by his mother to be entertained with the girls of the harem" Ibrahim is the most lavish and lethargic King in the history of Ottoman Empire. Kosem Sultan and Prime Minister Mustafa Pasha rule country during this period. (Eversely, 1959) In 1644, Mustafa Pasha was killed by Ibrahim order.[3]" On 8 August 1648, Ibrahim has been dethroned and imprisoned in the Topkapi Palace. The new Prime Minister Mehmed Pacha, Sofu, has asked the Sheikh Ul-Islam for a approval of the execution of fatwa against Ibrahim. It has been granted and Ibrahim was killed on 18 August 1648".

Kosem Sultan 7 years grandson Mehmed IV become new Sultan of Ottoman Empire and Kosem Sultan again get status of Naib-i- Sultanate from 1648 to 1651 .However, Turhan Sultan [ mother of Mehmed iv ] has been neglected because of Turhan inexperience and youth. Instead, Kosem Sultan has been restored to position of Naib-i- Sultanate. Kosem Sultan was a Valida Sultan under two sons, and thus has the most experience of the two women. Turhan Sultan want to prove to become Valida Sultan, Turhan was supported by the Prime Minister and other high government officials, while the body of the janissaries has supported Kosem. Although, in its position of Kosem Valida is regarded as the best for the Government, the people not appreciated the influence of janissaries [most dangerous army of all time] on the government. Finally, Sultan Mehmed also supports his mother Turhan and wants to dismiss Kosem Sultan. 
In this power fight back, Kosem planned to dethrone Mehmed and restore by another young grandson Suleiman son of Ibrahim .But before Kosem Sultan succeed, Turhan Sultan order her supporters to kill Kosem Sultan .After her death, Kosem body was buried in the mausoleum of her husband Ahmed I.

No doubt, she was the best Valida Sultan in the history of Sultanate of women. Her services for benefit of Turk nation are still appreciated in modern Turkey .She was the best administrator and know very well how to handle the situation. Her era is golden period of Ottoman Empire.

\section{Turhan Sultan}

Turhan Sultan was the wife of the Ottoman Sultan Ibrahim (reign from 1640 to 48) and Valida Sultan as the mother of Mehmed IV (reign from 1648-87). Turhan Sultan was born in Ukraine in 1627. Her origin name is Nadia. When she was 12-year-old Khan of Crimea, present her to Harem of Ottoman Empire as a gift. Her original religion is Christian .Kosem Sultan makes her queen of her son Ibrahim. On 2 January 1642, she gives birth to Mehmed IV future Sultan. On 2 August 1648, her son Mehmed IV becomes Sultanate the age less than 7 years.

Turhan Sultan played an important role for the regency of his young son. As I already mentioned rivalry between Kosem Sultan and Turhan Sultan. After the death of Kosem Sultan, Turhan Sultan got the whole powers of Empire and became Valida Sultan with the murder of Turhan. She is second woman after Kosem Sultan who became (NAIB-i-Sultanate). However, she face two major problems, one is war for the island of Crete and second financial problems. To solve these problems she gives her absolute power to "Koprulu Mehmed Pasha" (Uyar, \& Erickson, 2009).

Whom she appointed as Prime Minister. Turhan Sultan was the last prominent woman in the Sultanate of woman. She died on 4 August 1683 at the age of 56 year. With her dead Sultanate of women also came to end. 


\section{Conclusion:}

We can sum up that Turkish Women had played dynamic role in the politics of Ottoman Empire, after the passing of Suleiman the extraordinary in 1566, no other progressive Sultan could deal with the tremendous realm they acquired. Debasement, partiality and backwardness began to sneak in quick couple with the appropriation of state posts .At that time Ottoman Empire also face financial problems, but this women in this worst situation gave space to get power and rule the Ottoman Empire which they maintain very nicely. Ottoman Empire endured for six centuries through the reigns of 36 Sultan's .After ruling six centuries Ottoman Empire disappeared from map of the world after World War 1. However, one of the important features of Ottoman Empire is dominant role of royal harem in political matter of empire. These women have extra ordinary political influence on King of Ottoman Empire .This period is known as Sultanate of women during the $16^{\text {th }}$ and $17^{\text {th }}$ centuries. These all women are royal concubines whose sons and grandsons are the Sultans of Sultanate. 


\section{References:}

Babinger, F. (1977). Mehmed the Conqueror and His Time. (Bollinger Series, No. 96.) Princeton: Princeton University Press.

Davison, R. H. (2015). Reform in the Ottoman Empire, 1856-1876 (Vol. 2325). Princeton University Press.

Eversely, L. (1959) Turkish Empire: Its growth and decay. Lahore: Premier Book House.

Inalcik, H. (1970). The Heyday and Decline of the Ottoman Empire. The Cambridge History of Islam, 1, 324-353.

Uyar, M., \& Erickson, E. J. (2009). A Military History of the Ottomans: From Osman to Ataturk: From Osman to Ataturk. ABC-CLIO.

Vaughan, D. M. (1954). Europe and the Turk: A Pattern of Alliances, 1350-1700. Ams Pr Inc. 34-35 